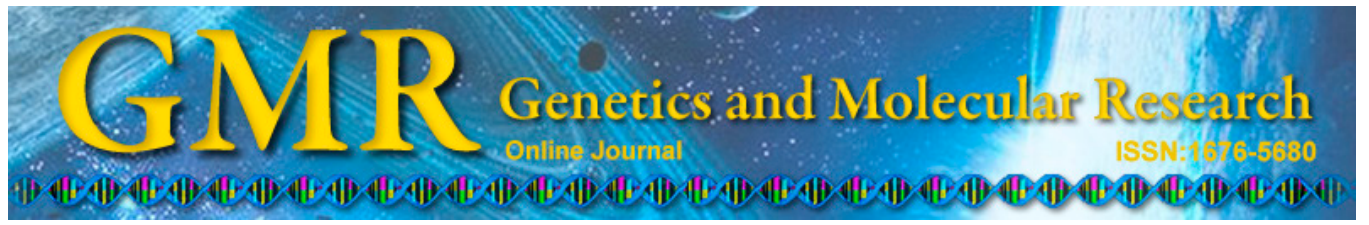

\title{
Georeferenced evaluation of genetic breeding value patterns in Brazilian Holstein cattle
}

\author{
N.S. Costa ${ }^{1}$, P. Hermuche ${ }^{1}$, J.A. Cobuci ${ }^{2}$, S.R. Paiva ${ }^{3}$, R.F. Guimaraes ${ }^{1}$, \\ O.A. Carvalho Jr. ${ }^{1}$, R.A.T. Gomes ${ }^{1}$, C.N. Costa ${ }^{4}$ and C.M. McManus ${ }^{1}$ \\ ${ }^{1}$ Universidade de Brasília, Brasília, DF, Brasil \\ ${ }^{2}$ Departamento de Zootecnia, Universidade Federal do Rio Grande do Sul, \\ Porto Alegre, RS, Brasil \\ ${ }^{3}$ EMBRAPA Sede, Brasília, DF, Brasil \\ ${ }^{4}$ EMBRAPA Gado de Leite, Juiz de Fora, MG, Brasil \\ Corresponding author: C.M. McManus \\ E-mail: concepta@unb.br
}

Genet. Mol. Res. 13 (4): 9806-9816 (2014)

Received January 2, 2014

Accepted June 4, 2014

Published November 27, 2014

DOI http://dx.doi.org/10.4238/2014.November.27.8

\begin{abstract}
The aim of this study was to analyze the relationship between environmental and genetic values for milk production and type traits in Holstein cattle in Brazil. The genetic value of 65,383 animals for milk production and 53,626 for type classification were available. Socioeconomic and environmental data were obtained from the Brazilian Institute of Geography and Statistics, the Food and Agriculture Organization of the United Nations, the National Aeronautics and Space Administration, and the National Institute of Meteorology. Five to six clusters were generated for each of the groups of type traits and production levels. The relationships between these traits were assessed using the STEPDISC, DISCRIM and CANDISC procedures in $\mathrm{SAS}^{\circledR}$. Traits within the clusters behaved differently, but, in general, animals with lower genetic values were found in environments that were more stressful for animal production. These differences were mainly associated with temperature, humidity, precipitation and the Normalized Difference Vegetative Index. Genetic values for milk
\end{abstract}


production showed best discrimination between different environments, while type traits showed poor discrimination, possibly because farmers mainly select for milk production. Environmental variations for genetic values in dairy cattle in Brazil should be further examined.

Key words: Conformation; Environment; Feet and legs; Type traits; Milk production; Udder

\section{INTRODUCTION}

According to the Food and Agriculture Organization of the United Nations (2013), there were nearly 1.5 billion cattle worldwide in 2010. Brazil ranks fifth in the world for milk production, producing 31 billion liters in 2011. The Brazilian cattle herd reached 209.5 million in 2010 according to the agricultural census (IBGE, 2010). The Holstein is the main milkproducing breed worldwide, with approximately $70 \%$ of milk production in Brazil coming from this breed and its crosses (Alvim et al., 2005).

Selection in dairy cattle production in Brazil has focused on milk production (Costa et al., 2008), but many countries have also incorporated other traits into their selection indices to increase the health and welfare of animals. Costa et al. (2009) stated that production during lactation has been used as the basis of genetic evaluations of cows and bulls in Brazil, but only larger farms are suited to take advantage of these genetic evaluations.

Gabbi et al. (2013) studied milk production in the tropics and found that feeding strategies, except salt supplementation, as well as monthly milk production, herd size, number of lactating cows in farm and unstable milk frequency were important discriminant variables for determining cluster formation; however, productivity did not vary between clusters. To compete on the international market, Brazil should adopt technological changes and increase production efficiency and quality. According to Barcellos et al. (2011), organizing information and access to technological advances is essential for guiding farmers, enabling them to manage their businesses and achieve higher levels of productivity and quality.

Environmental variables are important factors affecting milk production. Holderegger and Wagner (2006) proposed combining genetic information from populations with data from an environmental structure. According to Storfer et al. (2007), the genetic landscape explicitly quantifies the effects of landscape composition, configuration and matrix quality on gene flow and spatial genetic variation. Most of these studies use molecular data (Manel et al., 2003), while few have used breeding values to study spatial environmental variation.

In dairy cattle, animals of high genetic value reared in the country and animals from breeds of European origin adapted to the stressful conditions found in Brazil are generally unavailable (Silva et al., 2002). To overcome this, farmers use alternatives such as breeding with semen from animals selected abroad (Costa, 2013). Thus, genetic patterns in Brazil are not expected to correlate with the environments in which these animals are reared. Through the landscape genetic approach, environmental characteristics that influence the structure of genetic variation in breeds can be examined. Because of the importance of milk production in Brazil, it is necessary to study the characteristics that make up the landscape, along with the socioeconomic characteristics, so that producers can improve herd quality. In this study, we analyzed the relationship between environmental and socioeconomic conditions, genetic merit and type traits to determine their influence on milk production in Holstein cattle in Brazil. 


\section{MATERIAL AND METHODS}

The data available included the genetic value of 65,383 animals for 305-day milk and 53,626 type classifications from the Brazilian Association of Holstein Cattle Breeders. Brazil uses the Canadian standard linear classification system for Holstein cattle. Genetic values for these scores were estimated as described in Costa et al. (2009).

Each trait was scored on a scale of 1 to 9 . These values describe the degree of the trait rather than its desirability. Groups of traits and their weights in the final score (FS) were dairy form $(12 \%)$, conformation (18\%), feet and legs $(20 \%)$, mammary system (8\%), rump $(10 \%)$, front udder (14\%), and rear udder (18\%). Details can be found in Valloto and Ribas Neto (2010). The traits examined were as follows: ST, stature; TL, top line; WE, weight; CW, chest width; BD, body depth; LS, loin strength; RA, rump angle; RW, rump width; FA, foot angle; $\mathrm{BQ}$, bone quality; SV, side view of rear legs; FU, fore udder attachment; FT, fore teat placement; TL, teat length; RH, rear udder height; RW, rear udder width; RT, rear teat placement; UD, udder depth; UT, udder texture; UC, udder cleft; and AN, angularity.

Environmental and economic data in the study were obtained from different sources:

- Vegetation cover: 2011 annual average Normalized Difference Vegetation Index (NDVI), derived from Moderate Resolution Imaging Spectroradiometer (MODIS) images, acquired from the National Aeronautics and Space Administration (NASA) (2012) and processed using ENVI 4.5;

- Rainfall: average rainfall values from sensor images Tropical Rainfall Measuring Mission for 2000-2010, with a spatial resolution of $0.25^{\circ}$, or approximately $27 \mathrm{~km}$, acquired from NASA (2012) and processed using the Envi 4.7 software;

- Temperature: average of the period 2000-2010 from the Moderate Resolution Imaging Spectroradiometer (MODIS) images, product mod11, which consists of the mean monthly surface temperature with spatial resolution of $1 \mathrm{~km}$. Original images were acquired from NASA (2012) and redesigned in the program Moderate Resolution Imaging Spectroradiometer images Reprojection Tool (MRT extension geotif, geographic projection Lat/Long and Datum WGS 84).

- Altitude: based on data obtained from the Shuttle Radar Topography Mission, acquired from NASA (2012).

- Relative humidity: from the National Institute of Meteorology (INMET, 2012) and are the result of the average of a range of approximately 30 years of observation of 283 meteorological stations distributed throughout the territory.

- Gross domestic product, GDP: acquired from the Brazilian Institute of Geography and Statistics (IBGE, 2012a).

- Population: number of inhabitants in the year 2010 by region acquired from IBGE (2012) for the 2010 census.

- Municipal Area: acquired from IBGE (2012a).

- Variables collected from the 2006 Agricultural Census (IBGE, 2012b) and Municipal Animal Production Study (IBGE, 2012b) as in Table Annex.

- Human Development Index (HDI) from United Nations Development Programme (UNDP, 2013).

- Temperature and Humidity Index, THI: calculated from the data of temperature and humidity using the following formula: $\mathrm{THI}=\mathrm{Ta}+(0.36 \mathrm{x} \mathrm{To})+41.5$ - where Ta is the dry bulb temperature and To is the dew point temperature. 
Clusters were generated for the type classification groups [final index (FI), dairy character, conformation, feet and legs, mammary system and milk production] using the PROC FASTCLUS of SAS ${ }^{\circledR}$ (Statistical Analysis System, v.9.3, Cary, NC, USA). The clusters formed were spatialized in the ArcGIS 10 software. Analysis of variance was carried out to determine which socioeconomic and environmental characteristics differed between clusters. Discriminate analyses between clusters were performed using the procedures STEPDISC, DISCRIM, TREE, DISTANCE, CANCORR, and CANDISC in $\mathrm{SAS}^{\circledR}$ v. 9.3.

\section{RESULTS}

Generally, five to six clusters per group of characteristics were formed (Table 1). Within each group, the mean values of the different genetic characteristics varied. In general, clusters 5 and 6 showed the highest values for the characteristics and clusters 1 and 2 showed the lowest values for the same characteristics.

\begin{tabular}{|c|c|c|c|c|c|c|}
\hline & \multicolumn{6}{|c|}{ Cluster } \\
\hline & 1 & 2 & 3 & 4 & 5 & 6 \\
\hline \multicolumn{7}{|l|}{ Mammary } \\
\hline UD & 3.73 & -0.83 & 0.90 & -0.99 & 0.82 & 1.01 \\
\hline UT & 0.53 & -3.03 & -2.04 & -0.42 & 1.26 & 2.74 \\
\hline $\mathrm{UC}$ & 3.88 & -2.26 & -2.12 & -0.30 & 0.15 & 1.85 \\
\hline $\mathrm{FU}$ & -8.00 & -1.56 & 0.50 & -0.78 & 0.96 & 0.58 \\
\hline FT & -8.68 & -1.47 & -0.31 & -0.62 & 0.59 & 1.62 \\
\hline RH & -4.48 & -2.34 & -1.17 & -0.87 & 0.58 & 1.65 \\
\hline $\mathrm{RW}$ & -2.62 & -2.04 & -0.73 & -0.05 & 1.00 & 1.07 \\
\hline FU & 0.30 & -2.16 & -1.34 & -0.07 & 0.23 & 1.99 \\
\hline FT & -2.45 & 0.81 & -0.14 & 0.31 & -0.26 & -0.31 \\
\hline \multicolumn{7}{|l|}{ Dairy character } \\
\hline AN & -4.67 & -2.88 & -1.20 & -0.60 & 1.37 & 2.51 \\
\hline \multicolumn{7}{|l|}{ Feet and legs } \\
\hline FA & 3.24 & -5.37 & -0.09 & 4.17 & 0.43 & \\
\hline $\mathrm{BQ}$ & -5.66 & 0.19 & -0.92 & -1.01 & 2.37 & \\
\hline SV & -4.20 & -0.23 & -0.05 & -2.93 & -0.04 & \\
\hline \multicolumn{7}{|l|}{ Conformation } \\
\hline RA & -1.94 & -4.03 & 0.72 & -0.19 & -1.42 & 2.93 \\
\hline RW & -2.86 & 0.42 & -2.75 & 0.18 & 2.98 & -0.68 \\
\hline ST & -2.59 & -1.79 & 0.39 & -0.92 & 1.35 & 3.99 \\
\hline $\mathrm{TL}$ & -1.78 & -0.20 & -0.26 & 0.19 & 1.77 & 5.10 \\
\hline $\mathrm{CW}$ & -1.08 & -3.11 & -1.00 & 1.02 & 1.01 & 2.54 \\
\hline $\mathrm{BD}$ & -1.61 & -1.87 & -0.56 & 0.31 & 1.49 & 4.36 \\
\hline LS & -1.64 & 0.22 & 0.34 & -1.05 & 1.61 & 4.09 \\
\hline WT & -2.63 & -2.66 & -0.23 & -0.21 & 1.72 & 5.45 \\
\hline \multicolumn{7}{|l|}{ Final score } \\
\hline & -4.49 & -2.21 & -0.22 & 1.86 & 3.97 & 6.45 \\
\hline \multicolumn{7}{|l|}{ Milk production } \\
\hline MP & -0.29 & -0.03 & 0.16 & 0.38 & 0.62 & \\
\hline
\end{tabular}

Characteristics linked to pasture quality and thermal comfort were the most important 
factors affecting the distribution of genetic values for milk production and type traits (Table 2). These included Normalized Difference Vegetation Index, precipitation, temperature amplitude, relative humidity, altitude above sea level and mean temperatures, as well as THI.

Table 2. Effect of climatic and socioeconomic factors on genetic values for milk production and type of Holstein cattle in Brazil.

\begin{tabular}{|c|c|c|c|c|c|c|}
\hline Abbreviation & Conformation & Mammary system & Feet and legs & Dairy character & Final score & Milk production \\
\hline Farm data & & & & & & \\
\hline Area & * & & & * & * & * \\
\hline Non-family agriculture & * & & & & & \\
\hline Animals and crops & & & & & * & * \\
\hline Income & & & & * & * & \\
\hline \multicolumn{7}{|l|}{ Plant production } \\
\hline Planted forest & & * & & & & \\
\hline Horticulture and floriculture & & * & * & & & * \\
\hline$\%$ Farm used for plant production & * & & & & * & \\
\hline Crops & * & & * & * & * & * \\
\hline Natural forest and shrub & & * & & & & * \\
\hline \multicolumn{7}{|l|}{ Animal Production } \\
\hline Animals & & * & & & * & * \\
\hline Aquiculture & * & * & & & & \\
\hline Cultivated pasture & & & & & * & * \\
\hline Manure & & & * & * & & \\
\hline Poultry & * & & & & & \\
\hline Bovines & & * & & & & * \\
\hline Small ruminants & * & * & & & & * \\
\hline Equines & * & & & & * & * \\
\hline \multicolumn{7}{|l|}{ Social Factors } \\
\hline HDI & * & & * & & & * \\
\hline Extension from cooperatives and NGOs & & $*$ & $*$ & * & * & \\
\hline \multicolumn{6}{|l|}{ Water sources } & * \\
\hline $\begin{array}{l}\text { Lakes and springs protected by } \\
\text { shrub and forest }\end{array}$ & $*$ & $*$ & $*$ & & & \\
\hline Artesian wells & & * & & & * & \\
\hline $\begin{array}{l}\text { Lakes and rivers not protected by } \\
\text { shrub and forest }\end{array}$ & & & & & & * \\
\hline \multicolumn{7}{|l|}{ Climatic and geographic features } \\
\hline Altitude & * & & * & * & & \\
\hline Temperature Amplitude & * & * & & * & & * \\
\hline THI & * & * & & * & & \\
\hline NDVI & * & * & * & * & * & * \\
\hline Precipitation & & * & & * & * & * \\
\hline Relative humidity & * & * & & & & \\
\hline Temperature & * & & & & & * \\
\hline
\end{tabular}

*Significant features in the division of clusters. THI = Temperature Humidity Index; NDVI = Normalized Difference Vegetation Index; HDI = Human Development Index.

The number of goats and buffaloes in the region was also important. This is related to the fact that both are used for milk production and they require similar milk processing plants and distribution networks.

Higher genetic values for milk production were associated with regions with more planted crops (including pasture) and animals, larger farms and less natural forest, shrub as well as rivers and lakes not protected by natural forest or shrubs. They were also related to regions with a higher Human Development Index. Farmers generally contracted their own advisory services rather than used that provided by cooperatives and non-governmental organizations. 
The separation of clusters by discriminant analysis for conformation clusters generally showed a rating of less than $50 \%$ of municipalities correctly classified within their cluster of origin (Table 3), with the best classification for milk production $(>50 \%)$.

Table 3. Percentage of correct classification within each cluster formed by the genetic values of type traits and
milk production.
\begin{tabular}{lcccccc} 
Cluster & Conformation & Mammary system & Legs and feet & Dairy character & Final score & Milk production \\
\hline 1 & 27 & 57 & 44 & 30 & 27 & 67 \\
2 & 47 & 41 & 37 & 11 & 56 & 70 \\
3 & 36 & 42 & 75 & 31 & 29 & 53 \\
4 & 50 & 52 & 49 & 45 & 30 & 65 \\
5 & 51 & 35 & 36 & 52 & 20 & 75 \\
6 & 36 & 61 & & 44 & 24 & \\
\hline
\end{tabular}

Spatial clusters per group are shown in Figure 1. Minas Gerais, São Paulo, Paraná, Rio Grande do Sul and Goiás states showed both the highest and lowest values for each feature, highlighting the differences in environmental characteristics between the clusters of genetic values (Table 4). Clusters formed ranged from the lowest $(1,2,3)$ to highest $(4,5$, and 6$)$ genetic values within each group of type traits and milk production. For example, the cluster with the highest genetic merit for milk production (cluster 5, Table 2) showed lowest average and minimum temperatures, as well as lower thermal amplitude variation during the year and higher precipitation.
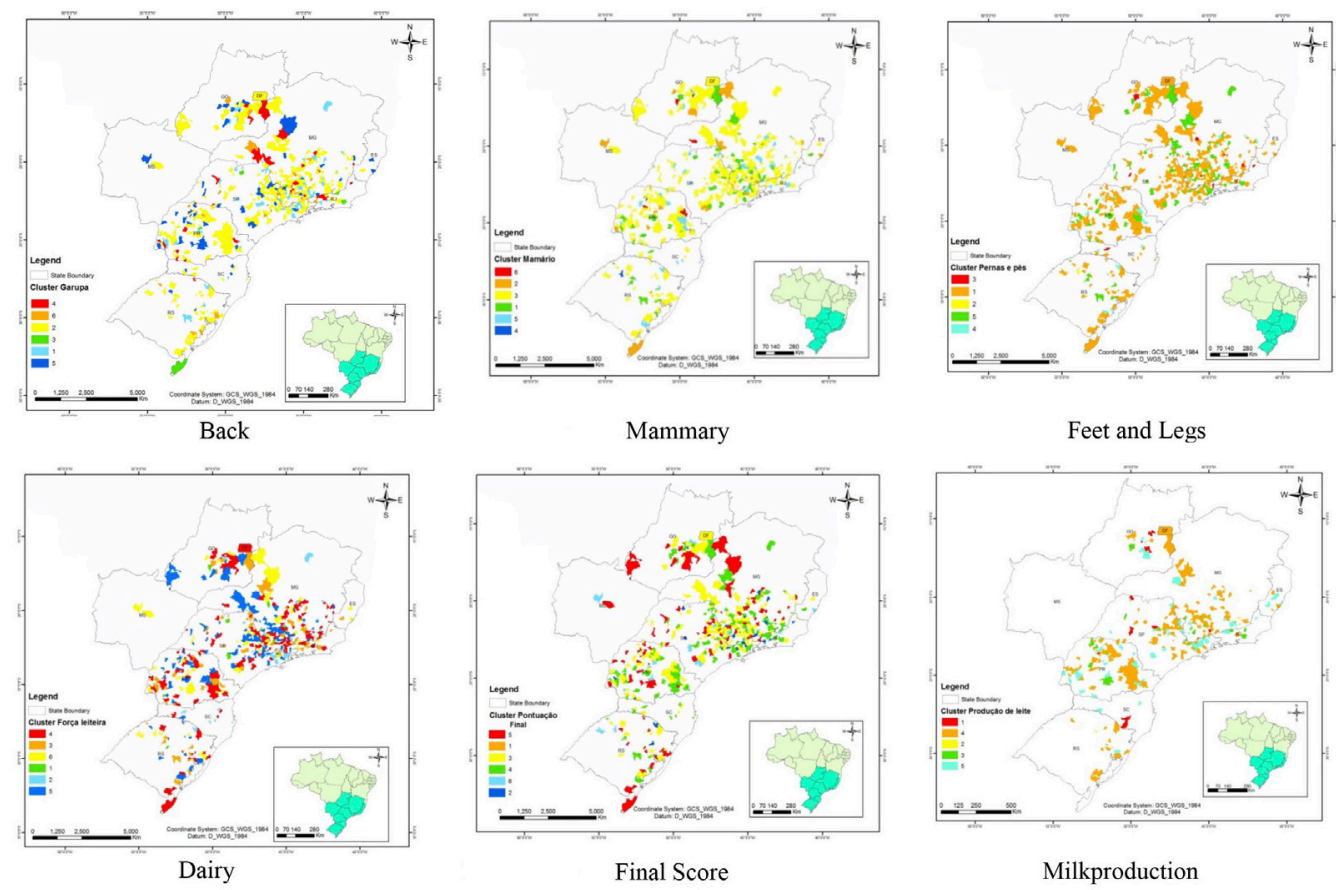

Figure 1. Cluster maps for genetic value in Holstein dairy cattle in Brazil by type and milk production [Cluster order is from the worst (1) to the best (5 or 6)]. 
Table 4. Averages of the main enviromental features per cluster for Holstein cattle in Brazil.

\begin{tabular}{|c|c|c|c|c|c|c|}
\hline & \multicolumn{6}{|c|}{ Cluster } \\
\hline & 1 & 2 & 3 & 4 & 5 & 6 \\
\hline \multicolumn{7}{|l|}{ Conformation } \\
\hline Temperature amplitude & 8.20 & 7.91 & 7.72 & 7.64 & 7.59 & 7.79 \\
\hline Altitude & 679.33 & 786.97 & 618.78 & 737.17 & 662.61 & 630.73 \\
\hline $\mathrm{NDVI}^{2}$ & 0.37 & 0.28 & 0.35 & 0.30 & 0.41 & 0.29 \\
\hline Relative humidity $^{2}$ & 68.79 & 60.97 & 62.83 & 64.51 & 64.67 & 64.71 \\
\hline Mean daily temperature & 26.36 & 26.77 & 26.78 & 26.12 & 26.74 & 25.99 \\
\hline Temperature humidity index & 75.48 & 75.92 & 75.96 & 75.09 & 75.88 & 74.86 \\
\hline \multicolumn{7}{|l|}{ Mammary system } \\
\hline Temperature amplitude & 7.87 & 8.02 & 7.65 & 8.05 & 7.83 & 7.71 \\
\hline Precipitation $^{2}$ & 1649.25 & 1584.18 & 1543.08 & 1372.09 & 1531.31 & 1566.4 \\
\hline $\mathrm{NDVI}^{2}$ & 0.39 & 0.32 & 0.31 & 0.30 & 0.33 & 0.29 \\
\hline Relative humidity & 73.46 & 73.37 & 72.81 & 70.47 & 73.35 & 73.16 \\
\hline Temperature humidity index & 74.81 & 75.58 & 75.45 & 78.83 & 74.8 & 74.27 \\
\hline \multicolumn{7}{|l|}{ Feet and legs } \\
\hline Minimum temperature & 23.86 & 21.17 & 21.64 & 22.16 & 21.8 & \\
\hline $\mathrm{NDVI}^{2}$ & 0.16 & 0.31 & 0.31 & 0.35 & 0.30 & \\
\hline Human development index & 0.74 & 0.75 & 0.77 & 0.75 & 0.77 & \\
\hline Altitude & 521.57 & 689.48 & 687.66 & 616.86 & 739.84 & \\
\hline \multicolumn{7}{|l|}{ Dairy form } \\
\hline Mean daily temperature & 27.08 & 25.43 & 25.68 & 25.51 & 25.72 & 26.73 \\
\hline Precipitation $^{2}$ & 1545.55 & 1601.71 & 1510.66 & 1552.15 & 1567.68 & 1469.15 \\
\hline Altitude & 803.33 & 680.14 & 779.61 & 734.85 & 676.62 & 529.43 \\
\hline $\mathrm{NDVI}^{2}$ & 0.39 & 0.30 & 0.31 & 0.32 & 0.32 & 0.27 \\
\hline Temperature Humidity Index & 76.37 & 75.87 & 75.82 & 74.95 & 74.8 & 74.56 \\
\hline \multicolumn{7}{|l|}{ Final score } \\
\hline Precipitation $^{2}$ & 1645.57 & 1546.88 & 1525.79 & 1583.12 & 1440.99 & 1452.14 \\
\hline NDVI & 0.63 & 0.59 & 0.61 & 0.61 & 0.63 & 0.54 \\
\hline Value of receipts & $37,304.6$ & 40.520 & $49,750.6$ & $44,234.4$ & $20,659.8$ & 6492.96 \\
\hline \multicolumn{7}{|l|}{ Milk production } \\
\hline Minimum temperature & 23.19 & 21.25 & 21.38 & 22.17 & 20.88 & \\
\hline Temperature amplitude & 8.47 & 7.57 & 7.55 & 7.88 & 7.39 & \\
\hline Precipitation $^{2}$ & 1594.17 & 1525.35 & 1587.62 & 1607.09 & 1705.58 & \\
\hline Precipitation & 0.19 & 0.2 & 0.19 & 0.19 & 0.19 & \\
\hline Mean daily temperature & 27.98 & 26.01 & 26.02 & 26.26 & 26.00 & \\
\hline
\end{tabular}

NDVI $=$ Normalized Difference Vegetative Index.

Genetic values for type traits were highly influenced by climatic and geographical features. In general, animals with higher genetic values were found in regions with better environmental conditions (Table 4).

Overall, the canonical analyses (Figure 2) confirmed the results shown in Table 4, linking the values of each environmental characteristic with distinct clusters generated for each type section and for milk production.

\section{DISCUSSION}

The THI was important in separating conformation, mammary system and milk and reinforcing the analyses above, where the most important variables were related to climatic factors. This ratio directly influences the quality of the pasture and the animal's body temperature. Precipitation was considered an important feature in the separation of the mammary system, dairy form, final score and milk production. This directly affects the quality of the pasture and the air temperature on the farm where cattle are reared.

When Holstein cows are subjected to high temperatures, milk production generally decreases. The cow is more sensitive to heat stress as milk production increases, produc- 
ing a larger amount of metabolic heat (Vasconcelos and Demetrio, 2011). Selection for milk production reduces the thermoregulatory capacity of dairy cows and may further increase the susceptibility of these to heat stress, decreasing milk production and reproductive efficiency. Determining whether the animal is in a stressful environment is crucial for physiological efficiency and economic exploitation (Scholtz et al., 2011).

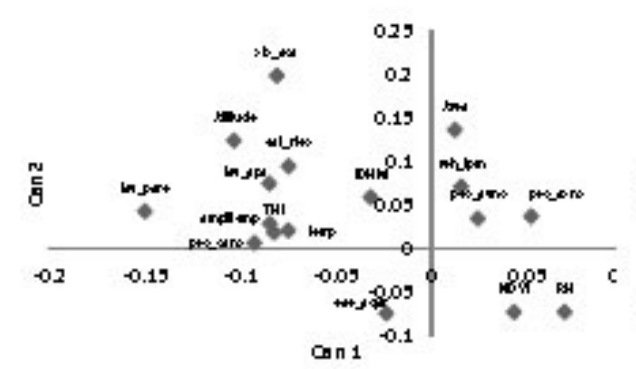

Back

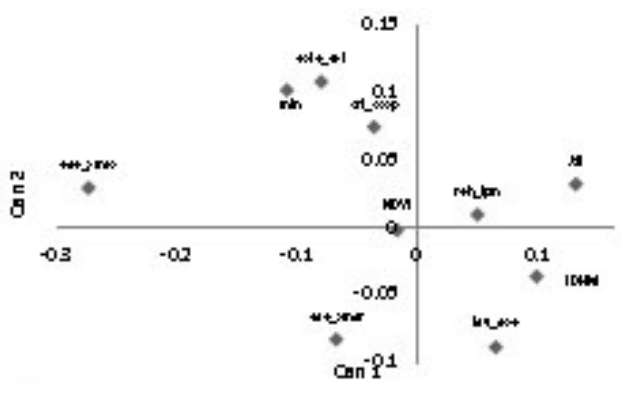

Feet and Legs

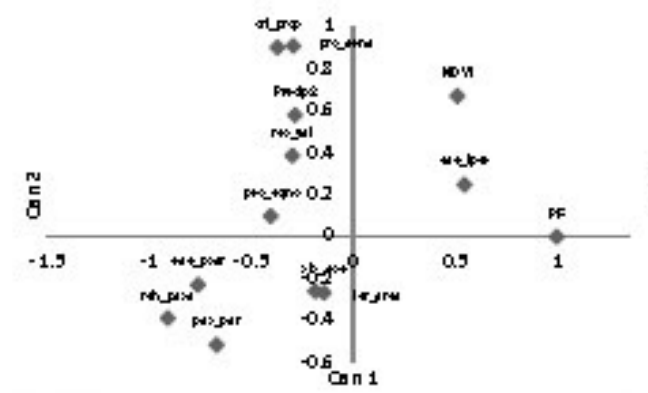

Fìnal Score

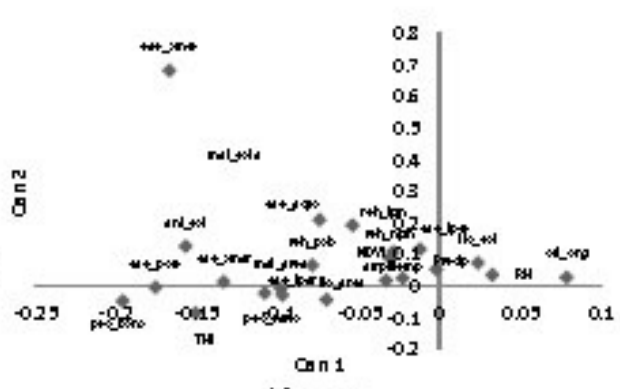

Marcucary

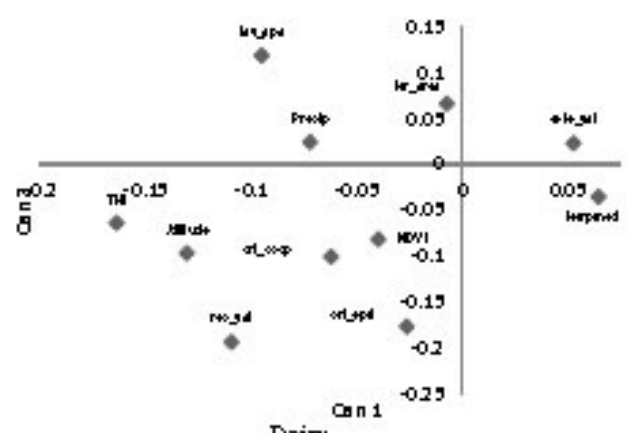

Dairy

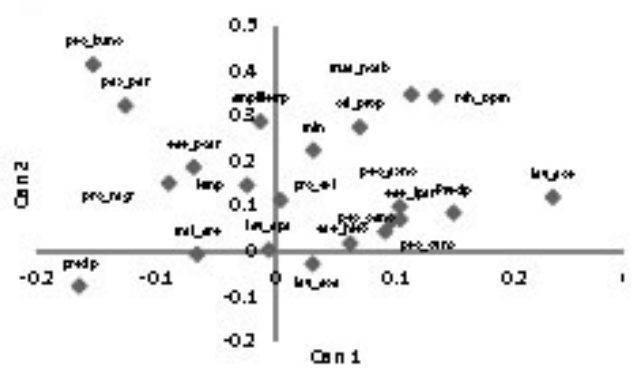

Milk Production

Figure 2. Canonical Analysis of environmental data separating clusters of genetic values for type and milk production traits in Holstein cattle in Brazil (Table S1).

Temperature variations affect the production and quality of milk. According to Gabbi et al. (2013), heat stress affects the physiological condition of the animal and can alter the characteristics of milk produced, including reducing stability. This perception is critical for analyzing the characteristics affecting milk production. Gaughan et al. (2008) state that 
climate change is perceived as a major threat to the survival of many species and ecosystems, as well as affects the financial sustainability of pastoral systems in various parts of the world, particularly in developing countries. Holsteins are of European origin and showed higher genetic values under more temperate conditions, particularly in the southern region of the country. Two hypotheses support this observation: i) farmers in more temperate regions have better selection for milk and/or ii) genetic evaluation could not remove all environmental effects. Both theories require further study, but it is known that in states such as Paraná, the Breeders' Association is more structured, farmers are better informed, and there is more intense selection for milk production.

In general, the clusters formed by type traits were not efficient (Table 3), whereas the percentage of correct classification in each cluster was higher for milk production. The values used for spatialization were adjusted according to the genetic value of the animal. Of the population studied, approximately $10 \%$ of cows were born through artificial insemination using imported semen. Thus, in theory, the environment should not influence the distribution of genetic value of these animals. The other $90 \%$ was born through natural service or locally acquired semen. Milk production is the most important factor considered when purchasing semen or choosing a bull for natural service. One factor that may have affected the distribution was that farmers in environments more appropriate for milk production buy more expensive semen with higher genetic value for this trait.

In terms of type classification, each group of features behaved differently; however, in general, animals with lower genetic values were found in poorer environments and the animals faced a greater number of challenges. Animals with higher genetic values within each section were found in areas with better environmental conditions (higher Normalized Difference Vegetation Index, higher rainfall, lower temperature range). Animals with better legs and feet were found in areas with higher altitude. This may reflect the slope of the region where animals were selected for these features, as these traits are important for the health and longevity of animals in the herd. Pérez-Cabal et al. (2006) found a positive relationship between the genetic value for feet and legs and milk production. Additionally, these regions are generally colder and have a lower temperature range. An anomaly was observed for the final score, where animals with better scores were related to lower revenue and worse environmental conditions. The explanation may be that larger animals have a lower breeding value for milk production but better general conformation. Campos et al. (2012) showed that selection for final score should not increase milk production because of the low correlations between these characteristics. Onyiro and Brotherstone (2008) found that the breeding system affected scores for linear type, which is in accordance with the present results, as differences were observed among environments for type traits and milk production.

\section{CONCLUSION}

Breeding values for type traits and milk production differed according to environmental factors such as rainfall and temperature, indicating that these factors influence the distribution of genetic values of dairy traits within Brazil. These environmental factors should be studied further to increase the understanding of the environmental effects on type traits and milk production in Holsteins in Brazil. 


\section{ACKNOWLEDGMENTS}

We would like to thank the Associação Brasileira dos Criadores de Bovinos da Raça Holandesa (ABCBRH) for the use of the data. Research supported by INCT Pecuária $(\mathrm{CNPq} /$ MCT/FAPEMIG), CNPq Edital Universal, CNPq, and CAPES.

\section{$\underline{\text { Supplementary material }}$}

\section{REFERENCES}

Alvim MJ, Paciullo DSC, Carvalho MM and Aroeira LJM (2005). Sistema de Produção de Leite com Recria de Novilhas em Sistemas Silvipastoris. EMBRAPA CNPTIA. Available at [http://sistemasdeproducao.cnptia.embrapa.br/ FontesHTML/Leite/LeiteRecriadeNovilhas/alimentacao.htm]. Accessed August 22, 2012.

Barcellos JOJ, Queiroz Filho LA, Ceolin AC and Gianezini M (2011). Technological innovation and entrepreneurship in animal production. Braz. J. Anim. Sci. 40: 189-200.

Campos RV, Cobuci JA, Costa CN and Neto JB (2012). Genetic parameters for type traits in Holstein cows in Brazil. Braz. J. Anim. Sci. 41: 2150-5161.

Costa CN (2013). Impacto das Importações de Sêmen na Melhoria Genética da Raça Holandesa no Brasil. Available at [http://www.milkpoint.com.br/?actA=7\&areaID=61\&secaoID=171\&noticiaID=25031]. Accessed March 5, 2013.

Costa CN, Melo CMR, Packer IU and Freitas AF (2008). Genetic parameters for test day milk yield of first lactation Holstein cows estimated by random regression using Legendre polynomials. Rev. Bras. Zootec. 37: 602-608.

Costa CN, Freitas AF, Cobuci JA and Guimarães MFM (2009). Sumário Nacional de Touros da Raça Holandesa. 1st edn. Embrapa, Juiz de Fora.

FAO (Food and Agriculture Organization of the United Nations) (2013). Statistics: Animal Productions. Available at [http://www.fao.org/index_en.htm]. Accessed July 21, 2013.

Gabbi AM, McManus CM, Silva AV and Marques LT (2013). Typology and physical-chemical characterization of bovine milk produced with different productions strategies. Agric. Syst. 121: 130-134.

Gaughan JB, Mader TL, Holt SM and Lisle A (2008). A new heat load index for feedlot cattle. J. Anim. Sci. 86: 226-234.

Holderegger R and Wagner HH (2006). A brief guide to landscape genetics. Land Ecol. 21: 793-796.

IBGE (Instituto Brasileiro de Geografia e Estatística) (2006). Censo Agropecuário. Available at [http://www.ibge.gov.br/ home/estatistica/economia/agropecuaria/censoagro/default.shtm] Accessed May 5, 2012.

IBGE (Instituto Brasileiro de Geografia e Estatística) (2010). Comentários. Available at [http://www.ibge.gov.br/home/ estatística/economia/ppm/2010.comentários.pdf]. Accessed November 11, 2014.

IBGE (Instituto Brasileiro de Geografia e Estatística) (2012a). Geociências-Geografia. Available at [http://www.ibge.gov. br/home/geociencias/geografia/default.shtm]. Accessed June 8, 2012.

IBGE (Instituto Brasileiro de Geografia e Estatística) (2012b). Sistema IBGE de Recuperação Automática-SIDRA. Available at [http://www.sidra.ibge.gov.br/]. Accessed May 18, 2012.

INMET (Instituto Nacional de Meteorologia) (2012). Available at [http://www.inmet.gov.br/portal/index.php?r=bdmep/ bdmep]. Accessed May 20, 2012.

Manel S, Schwartz MK, Luikart G and Taberlet P (2003). Landscape genetics: combining landscape ecology and population genetics. Trends Ecol. Evol. 18: 189-197.

NASA (National Aeronautics and Space Administration) (2012). Catálogo de Imagens. Available at [http://reverb.echo. nasa.gov/reverb/\#utf8=\%E2\%9C\%93\&spatial_map=satellite\&spatial_type=rectangle]. Accessed February 21, 2012.

Onyiro OM and Brotherstone S (2008). Genetic analysis of locomotion and associated conformation traits of HolsteinFriesian dairy cows managed in different housing systems. J. Dairy Sci. 91: 322-328.

Pérez-Cabal MA, García C, González-Recio O and Alenda R (2006). Genetic and phenotypic relationships among locomotion type traits, profit, production, longevity, and fertility in Spanish dairy cows. J. Dairy Sci. 89: 1776-1783.

Scholtz MM, McManus C, Okeyo AM and Theunissen A (2011). Opportunities for beef production in developing countries of the southern hemisphere. Livest. Sci. 142: 195-202.

Silva IJO, Pendorfi H, Acararo I and Piedade SMS (2002). Efeitos da climatização do curral de espera na produção de leite de vacas holandesas. R. Bras. Zootec. 31: 2036-2042.

Storfer A, Murphy MA, Evans JS and Goldberg CS (2007). Putting the 'landscape' in landscape genetics. Heredity 98: $128-142$. 
UNDP (2013). United Nations Development Programme Human Development Report. Available at [http:/hdr.undp.org/ en/content/human-development-report-2013-media-toolkit]. Acessed April 23, 2013.

Valloto AA and Ribas Neto PG (2010). Raça Holandesa Moderniza e Atualiza Sistema de Avaliação da Conformação das Vacas (Classificação Para Tipo). Available at [http://www.gadoholandes.com.br/wa_files/Modernizacao_20sistema 20classificacao.pdf]. Accessed November 15, 2013.

Vasconcelos JLM and Demetrio DGB (2011). Manejo reprodutivo de vacas sob estresse calórico. Rev. Bras. Zootec. 40: 396-401. 